\title{
PENGARUH KEPUASAN KERJA DAN KETERLIBATAN KERJA TERHADAP KOMITMEN ORGANISASI KARYAWAN BADAN TENAGA NUKLIR NASIONAL (BATAN) PUSPIPTEK SERPONG
}

\author{
Feny Vitaria Arumsari \\ feny.vas@gmail.com \\ Fakultas Psikologi UIN Syarif Hidayatullah Jakarta
}

\begin{abstract}
This research conducted to discover the effect of job satisfication and involvement of work toward employee organization's commitment. The sample of this research were some employees of Badan Tenaga Nuklir Nasional (BATAN), PUSPIPTEK Serpong as much as 200 employee with probability sampling technique. The data analysis used Multiple Regression Analysis on the significant level of 0,05. The result of this research showed that there was a significant effect of job satisfication, and involvement of work toward employee organization's commitment. The proportion of variance from commitment organization that have been explained by all independent variable is $35,7 \%$, meanwhile the $64,3 \%$ are affected by other variables from the outside of this research. The result of minor hypotesis test pointed that communication, importance of performance with valued self and concistency with self concept having significant effect toward commited organization. Meanwhile, salary, promotion, sepervision, allowance, reward, operational procedure, work partner, work behaviour, central life interest and active participation were not having significant effect toward commitment organization.
\end{abstract}

Keywords:commitment organization, job satisfication, involvement of work

\begin{abstract}
Abstrak
Penelitian ini dilakukan untuk mengetahui pengaruh kepuasan kerja dan keterlibatan kerja terhadap komitmen organisasi karyawan. Sampel dalam penelitian ini adalah karyawan Badan Tenaga Nuklir Nasional (BATAN) PUSPIPTEK Serpong sebanyak 200 karyawan. Teknik sampling yang digunakan adalah probability sampling. Analisis data yang digunakan adalah Multiple Regression Analysis pada taraf signifikansi 0,05. Hasil penelitian menunjukkan bahwa terdapat pengaruh yang signifikan kepuasan kerja dan keterlibatan kerja terhadap komitmen organisasi karyawan. Proporsi varians dari komitmen organisasi yang dijelaskan oleh semua independent variable adalah sebesar $35,7 \%$, sedangkan $64,3 \%$ sisanya dipengaruhi oleh variabel lain diluar penelitian ini. Hasil uji hipotesis minor menunjukkan bahwa komunikasi, importance of performance with valued self dan concistency with self concept memiliki pengaruh yang signifikan terhadap komitmen organisasi. Sementara itu, gaji, promosi, supervisi, tunjangan, penghargaan, prosedur
\end{abstract}


operasional, rekan kerja, sifat pekerjaan, central life interest dan active participation tidak memiliki pengaruh signifikan terhadap komitmen organisasi.

Kata kunci: Komitmen organisasi, kepuasan kerja, keterlibatan kerja

\section{PENDAHULUAN}

Salah satu masalah nasional yang dihadapi bangsa Indonesia saat ini adalah penanganan terhadap rendahnya kualitas sumber daya manusia. Jumlah sumber daya yang besar apabila dapat didayagunakan secara efektif dan efisien akan bemanfaat untuk menunjang gerak lajunya pembangunan nasional yang berkelanjutan. Melimpahnya sumber daya manusia yang ada saat ini mengharuskan suatu organisasi berfikir secara optimal yaitu bagaimana memanfaatkan sumber daya manusia secara maksimal. Banyak organisasi atau perusahaan yang menghadapi tantangan ini dengan membangun komitmen organisasi dari para karyawan dalam upaya meningkatkan kualitas.

Banyak perusahaan di Indonesia menghadapi masalah dalam mempertahankan karyawan (turnover) sebagai bentuk minimnya komitmen karyawan terhadap organisasi. Hasil survey Global Srategic Reward 2007/2008 yang dilakukan oleh Watson Wyatt (Setiadi dkk, 2010), pada sektor perbankan di Indonesia menemukan bahwa tingkat turnover pada posisi penting (manajer dan diatasnya) tingkat turnover berkisar antara 6,3$7,5 \%$. Sedangkan pada sektor industry tingkat turnover umumnya hanya berkisar antara $0,1-0,74 \%$. Tingginya perputaran turnover tenaga kerja dapat menimbulkan masalah yang serius, terutama pada sektor jasa yang mempunyai aktifitas melayani manusia maupun para klien dimana tingkat perputaran tenaga kerja sering melebihi $25 \%$ pertahunnya, Gallon, Gabriel, \& Knudsen (dalam Aarons \& Sawitzky, 2006).

Fenomena lain yang berkembang saat ini dalam dunia industri dan organisasi yaitu para profesional cenderung lebih berkomitmen terhadap profesi daripada perusahaan tempatnya bekerja. Karyawan yang berkomitmen terhadap profesi tidak selalu merujuk pada suatu organisasi, sehingga karyawan seperti ini selalu berpindah-pindah kerja ke tempat lain (Fineman dkk, 2005). Sejalan dengan penelitian tersebut, ada sebagian karyawan Badan Tenaga Nuklir Nasional PUSPIPTEK Serpong yang memilih untuk mencari pekerjaan sampingan lainnya diluar kantor seperti profesi sebagai dosen, konsultan, dll. Fenomena tersebut salah satunya disebabkan oleh adanya kesenjangan antara karyawan yang bekerja disatu perusahaan dengan karyawan yang bekerja di tempat lain, walaupun mereka memiliki jobdesk yang sama. Beberapa orang yang terpengaruh pada akhirnya mengambil keputusan untuk berpindah kerja ke perusahaan lain, 
tapi tidak sedikit pula yang memutuskan untuk tetap bekerja di perusahaan terkait.

Selama bertahun-tahun komitmen organisasi telah dikonseptualisasikan dan didefinisikan dalam beberapa cara oleh penulis yang berbeda. Buchanan, 1974 (dalam Allen \& Meyer, 1990) mendefinisikan komitmen organisasi sebagai sebuah partisipasi aktif dalam mengikuti tujuan dan nilai-nilai organisasi yang berkaitan dengan tujuan dan aturan. Mowday, 1979 (dalam Allen \& Meyer, 1990) mendefinisikan komitmen organisasi sebagai identifikasi kekuatan individu dengan keterlibatan dalam organisasi tertentu.

Adapun faktor yang mempengaruhi komitmen organisasi menurut Stum, 1998 (dalam Sopiah, 2008) menjelaskan bahwa terdapat lima faktor yang berpengaruh terhadap komitmen organisasi yaitu, diantaranya yaitu: (1) budaya keterbukaan (2) kepuasan kerja (3) kesempatan personal untuk berkembang (4) arah organisasi dan (5) penghargaan kerja sesuai yang dibutuhkan. Sedangkan menurut David (dalam Sopiah, 2008) menjelaskan faktor-faktor yang mempengaruhi komitmen organisasi yaitu: (1) Faktor personal (usia,masa kerja, tingkat pendidikan, jenis kelamin), karakteristik pekerjaan (jabatan, tantangan, konflik dan tingkat kesulitan pekerjaan) (3) karakteristik struktur (besar / kecilnnya organisasi, bentuk organisasi, kehadiran serikat kerja dan kontrol organisasi terhadap karyawan), dan (4) Pengalaman kerja, pengalaman kerja karyawan sangat berpengaruh terhadap tingkat komitmen karyawan pada organisasi. Karyawan yang baru beberapa tahun bekerja tentu akan berbeda dengan karyawan yang sudah bekerja selama puluhan tahun.

Dalam penelitian ini, peneliti mengambil kepuasan kerja dari faktor yang dijelaskan oleh Stum, 1998 (dalam Sopiah, 2008) sebagai variabel pertama dan keterlibatan kerja dari faktor karakteristik pekerjaan yang dijelaskan oleh David (dalam Sopiah, 2008) sebagai variabel kedua.

Terkait dengan komitmen organisasi, ada berbagai penelitian yang mengeksplorasi variabel yang berkaitan dengan komitmen organisasi, yaitu variabel kepuasan kerja dan komitmen organisasi diantaranya penelitian Agho, Price \& Mueller, 1992 (dalam Buitendach \& De Witte, 2005) yang menjelaskan bahwa karyawan yang merasa puas dengan pekerjaannya akan menunjukkan komiten organisasi yang lebih baik. Hal ini sesuai dengan pengukuran hasil dari 183 penelitian dan hampir 26.000 sampel memiliki hubungan yang signifikan dan positif antara komitmen organisasi dan kepuasan kerja (dalam Kreitner \& Kinicki, 2009). Sedangkan Luthan, 1995 dan Ganzach, 1998 (dalam Muhadi, 2007) menyatakan bahwa variabel kepuasan kerja yang mencakup gaji, promosi, supervisi, tunjangan, penghargaan, prosedur operasional, rekan kerja, sifat pekerjaan, dan komunikasi dapat terpenuhi maka komitmen terhadap organisasi akan timbul dengan baik, sehingga kepuasan kerja dapat berdampak positif terhadap komitmen organisasi. 
Lumley, 2011 menemukan bahwa hasil yang konsisten pada penelitian sebelumnya yaitu kepuasan kerja berkorelasi positif dengan komitmen organisasi. Kepuasan kerja sangat penting karena menyumbang keberhasilan organisasi, antara lain dapat meningkatkan produktivitas dengan produk dan pelayanan yang berkualitas, dan juga dapat menurunkan tingkat absensi. Disamping itu kepuasan kerja sangat penting karena dapat meningkatkan komitmen organisasi.

Keterlibatan kerja karyawan sangat berperan besar dalam suatu perusahaan ataupun suatu organisasi. Ada beberapa teori yang menjelaskan keterlibatan kerja. Brown \& Leigh, 1996 mendefinisikan keterlibatan kerja sebagai "The degree to which a person a identifies psychologically with his or here work and the importance of work to one's self image". Dimana seorang karyawan dikatakan terlibat dalam pekerjaannya apabila karyawan tersebut dapat mengidentifikasikan diri secara psikologis dengan pekerjaannya, dan menganggap kinerjanya penting untuk dirinya, selain untuk organisasi.

Teori yang mendasari adalah bahwa dengan mengetahui keterlibatan kerja karyawan dengan demikian maka para karyawan akan menjadi lebih termotivasi, lebih berkomitmen terhadap organisasi ataupun perusahaan, lebih produktif dan lebih puas dengan pekerjaan mereka.

Berdasarkan latar belakang masalah tersebut, peneliti melakukan penelitian dengan judul "Pengaruh Kepuasan Kerja dan Keterlibatan Kerja terhadap Komitmen Organisasi pada Karyawan Badan Tenaga Nuklir Nasional (BATAN) PUSPIPTEK Serpong".

\section{TEORI DAN HIPOTESIS}

\section{Komitmen organisasi}

Allen \& Meyer, 1990 mendefinisikan komitmen organisasi sebagai sebuah konsep yang memiliki tiga dimensi, yaitu affective, normative, dan continuance commitment. Sedangkan Mathis \& Jackson, 2000 (dalam Sopiah, 2008) memberikan definisi komitmen organisasi sebagai "Organizational Commitment is the degree to which employees believe in and accept organizational goals and desire to remain with the organization" (Komitmen organisasi adalah derajat karyawan percaya dan menerima tujuan organisasi dan mempunyai keinginan untuk tetap dengan organisasi). Selanjutnya, Kreitner \& Kinicki, 2009 menjelaskan bahwa komitmen organisasi mencerminkan tingkat individu mengidentifikasi dirinya dengan organisasi dan terkait dengan tujuan-tujuannya.

Berdasarkan uraian di atas, dapat disimpulkan bahwa komitmen organisasi adalah sikap karyawan yang tertarik dengan tujuan, nilai dan sasaran organisasi yang ditunjukkan dengan adanya penerimaan individu atas nilai dan tujuan organisasi serta memiliki keinginan untuk berafiliasi dengan organisasi dan kesediaan bekerja keras untuk organisasi sehingga 
membuat individu betah dan tetap ingin bertahan di organisasi tersebut demi tercapainya tujuan dan kelangsungan organisasi.

Berdasarkan Allen \& Meyer, 1990 terdapat tiga komponen dari komitmen yang merupakan karakteristik komitmen karyawan pada organisasi, yaitu :

\section{Affective Commitment}

Komitmen afektif didefinisikan sebagai emosi attachment yang positif pada organisasi. Pekerja yang memiliki komitment yang kuat mengidentifikasikan organisasi dan keinginan untuk tetap menjadi bagian dari organisasi. Sejalan dengan Kreitner \& Kinicki, 2009 menyatakan karyawan yang memiliki komitmen afektif yang kuat akan terus bekerja dalam organisasi karena mereka memang ingin (want to) melakukan hal tersebut.

\section{Continuance Commitment}

Komitmen kontinuans adalah "the awareness of the impossibility of choosing a different social identity...because of the immense penalties involved in making the switch. Stebbins, 1970 (dalam Allen \& Meyer,1991). Kesadaran akan ketidakmungkinan memilih identitas social lain ataupun alternatif tingkah laku yang lain karena adanya ancaman akan kerugian besar. Sejalan dengan Kreitner \& Kinicki, 2009 karyawan yang bekerja berdasarkan komitmen kontinuans akan bertahan dalam organisasi karena mereka butuh (need to) melakukan hal tersebut karena tidak adanya pilihan lain.

\section{Normative Commitment}

Komitmen normatif merefleksikan "a feeling of obligation to continue employment". Dengan kata lain, komitmen normatif berkaitan dengan perasaan wajib untuk tetap bekerja dalam organisasi. Kreitner \& Kinicki, 2009 menyatakan bahwa karyawan yang memiliki komitmen normative yang relative tinggi mereka merasa bahwa wajib (ought to) bertahan dalam organisasi. Sedangkan Wiener, 1982 (dalam Allen \& Meyer, 1991) mendefinisikan komponen komitmen ini sebagai tekanan normatif yang terinternalisasi secara keseluruhan untuk bertingkah laku tertentu sehingga memenuhi tujuan dan minat organisasi. Oleh karena itu, tingkah laku karyawan didasari pada adanya keyajinan tentang "apa yang benar" serta berkaitan dengan masalah moral.

\section{Kepuasan kerja}

Menurut Siegel dan Lane, 1982 (dalam Munandar, 2005) yang mendapatkan pengertian dari Locke, "Job satisfaction is the appraisal of one's job as attaining or allowing the attainment of one's important job values, providing these values are congruent with or help fulfill one's basic needs". Secara singkat, karyawan yang merasa puas dengan pekerjaannya adalah karyawan yang 
meniilai pekerjaannya sebagai suatu pencapaian atau penghargaan terhadap nilai-nilai pekerjaan dan penerimaan nilai tersebut sejalan dengan pemenuhan kebutuhan dasarnya. Sedangkan menurut Spector, 2000 "Job satisfaction is simply how people feel about their jobs and different aspects of their jobs. It is extent to which people like (satisfaction or dislike (dissatisfaction) their jobs". Kepuasan kerja dianggap sebagai suatu perasaan individu secara umum terhadap pekerjaannya ataupun sebagai rangkaian yang saling berhubungan dari sikap-sikap individu terhadap aspek-aspek pekerjaannya yang mana kepuasan kerja tersebut menggambarkan tingkatan dimana individu merasa puas atau tidak terhadap pekerjaannya. Lain halnya menurut Robert \& Kinicki, 2009 "Job satisfaction is an affective or emotional response toward various facets of one's job". Kesimpulan yang didapat dari penjelasan di atas adalah kepuasan kerja merupakan suatu respon emosional atau perasaan seorang karyawan terhadap berbagai macam aspek dari suatu pekerjaannya.

Menurut definisi di atas dapat diartikan bahwa kepuasan kerja bukanlah suatu konsep yang satu. Tetapi, karyawan bisa bicara secara relatif puas dengan satu aspek pekerjaannya dan juga merasa tidak puas dengan satu atau lebih pada aspek pekerjaan yang lainnya maka dapat disimpulkan bahwa kepuasan kerja adalah suatu perasaan emosional karyawan dalam pencapaian atau penghargaan terhadap pekerjaannya dan perasaan emosional tersebut meliputi rasa puas maupun tidak puas dari berbagai macam aspek pekerjaan.

Menurut Spector, 1997 (dalam Lumley, 2011) terdapat sembilan aspek (facet) yang berpengaruh terhadap kepuasan kerja seseorang. Kesembilan aspek tersebut yaitu :

a. Gaji (pay)

Aspek ini mengukur kepuasan karyawan yang meliputi gaji yang diterima dan adanya kenaikan gaji.

b. Promosi (promotion)

Aspek ini mengukur derajat kepuasan karyawan yang meliputi kebijaksanaan promosi, kesempatan untuk mendapatkan promosi.

c. Kepemimpinan (supervision)

Aspek ini mengukur kepuasan kerja seseorang terhadap atasannya.

d. Tunjangan (fringe benefits)

Aspek ini mengukur derajat individu merasa puas terhadap tunjangan tambahan yang diterima dari perusahaan.

e. Penghargaan (contingent rewards)

Aspek ini mengukur derajat individu merasa puas terhadap penghargaan yang diberikan berdasarkan hasil kerja.

f. Prosedur operasional (operating procedures)

Aspek ini mengukur kepuasan yang meliputi prosedur dan peraturan di tempat kerja.

g. Rekan kerja (coworkers) 
Aspek ini mengukur kepuasan berkaitan hubungan dengan rekan kerja, misalnya adanya hubungan dengan rekan kerja yang rukun dan saling melengkapi.

h. Sifat pekerjaan (nature of work)

Aspek ini mengukur kepuasan kerja terhadap hal yang berkaitan dengan pekerjaan itu sendiri.

i. Komunikasi (communication)

Aspek ini berkaitan dengan komunikasi yang berlangsung dalam perusahaan dengan komunikasi yang lancar.

\section{Keterlibatan kerja}

Saleh \& Hosek, 1976 (dalam Rakhesma, 2006) berpendapat bahwa keterlibatan kerja adalah tingkat seberapa jauh seseorang mengidentifikasikan diri terhadap pekerjaan, berpartisipasi aktif di dalamnya, dan menganggap bahwa kinerja sebagai bagian penting dari harga dirinya. Sedangkan Kanungo, 1982 (dalam Blau \& Boal, 1989) berpendapat bahwa keterlibatan kerja adalah identifikasi psikologis seseorang terhadap tugas-tugas khusus atau pekerjaan secara umum, yang tergantung pada pentingnya kebutuhan-kebutuhan (baik intrinsik maupun ekstrinsik) dan persepsi bahwa pekerjaan memiliki potensi untuk memuaskan kebutuhan-kebutuhannya. Keterlibatan kerja disimpulkan sebagai sebuah konsep kompleks yang didasarkan pada kognisi, afeksi dan tindakan (action). Menurut Keller, 1997 (dalam Rakhesma, 2006) keterlibatan kerja juga merupakan salah satu variabel yang penting untuk dimengerti dan dipahami karena sering digunakan untuk memprediksi kondisi di dalam organisasi, seperti tingkat ketidakhadiran kerja dan perpindahan kerja.

Dari berbagai pendapat di atas, dapat disimpulkan bahwa keterlibatan kerja merupakan peran aktif individu terhadap kerja yang menunjukkan perhatian (harapan), tanggung jawab, dan usaha (mobilitas ke atas) yang lebih besar secara kualitatif maupun kuantitatif dalam melakukan pekerjaan atau tugas. Dengan kata lain, keterlibatan kerja merupakan peran aktif individu dalam melakukan tugas yang menunjukkan seberapa jauh perhatian dan tanggung jawabnya, serta seberapa besar usahanya mengerjakan tugas.

Menurut Saleh \& Hosek, 1976 (dalam Rakhesma, 2006), keterlibatan kerja merupakan konsep yang kompleks berdasarkan aspek kognitif, aspek tindakan, dan aspek perasaan, yaitu:

\section{Central Life Interest}

Keterlibatan kerja akan muncul apabila pekerjaan dirasakan dianggap sebagai sumber utama terhadap harapan individu dan sumber kepuasan dari kebutuhan-kebutuhan yang utama (salient need) Kebutuhan yang utama ini akan menguat bila pekerjaan dipersepsikan mampu memenuhi kebutuhan- 
kebutuhannya sehingga akan membuat individu menghabiskan waktu, tenaga dan fikirannya untuk pekerjaannya.

\section{Active Participation}

Dalam bekerja individu seharusnya aktif berpartisipasi dalam pekerjaannya. Partisipasi aktif akan terjadi bila seseorang diberikan kesempatan yang seluas-luasnya dalam bekerja seperti kesempatan mengeluarkan gagasangagasannya, membuat keputusan yang berguna untuk perusahaan, kesempatan untuk belajar, mengeluarkan keahlian dan kemampuannya dalam bekerja. Seseorang yang terlibat dalam pekerjaannya akan megambil kesempatan yang diberikan untuk berpartisipasi aktif dalam bekerja, sehingga partisipasi aktif ini akan berpengaruh pada hasil kerja dan kerja yang memuaskan akan mempengaruhi rasa harga dirinya.

\section{Importance of Performance with Valued Self}

Seberapa jauh kinerja individu mempengaruhi harga dirinya (self esteem). Usaha kerja yang ditampilkan menggambarkan seberapa jauh seseorang yang terlibat pada pekerjaannya akan menganggap pentingnya pekerjaan tersebut bagi self esteem atau rasa keberhargaan diri pada diri seseorang. Hal ini bisa terlihat dari seberapa sering karyawan memikirkan tentang pekerjaannya yang belum terselesaikan setelah jam kerja selesai, masalah yang belum selesai menjadi pusat konsep diri yang berlaku dalam hati.

\section{Consistency with Self Concept}

Consistency with Self Concept dipandang sebagai sesuatu hal yang konsisten dengan konsep dirinya. Seseorang yang terlibat dalam pekerjaannya akan memiliki konsentrasi terhadap pekerjaannya sehinga bisa mempengaruhi konsistensi seseorang dalam konsep dirinya.

\section{Hipotesis Penelitian}

\section{Hipotesis Mayor}

Ha: Terdapat pengaruh yang signifikan antara kepuasan kerja dan keterlibatan kerja karyawan Badan Tenaga Nuklir Nasional (BATAN) PUSPIPTEK Serpong.

\section{Hipotesis Minor}

Ha1.1: Terdapat pengaruh yang signifikan gaji terhadap komitmen organisasi pada karyawan Badan Tenaga Nuklir Nasional (BATAN) PUSPIPTEK Serpong

Ha1.2: Terdapat pengaruh yang signifikan promosi terhadap komitmen organisasi pada karyawan Badan Tenaga Nuklir Nasional (BATAN) PUSPIPTEK Serpong 
Ha1.3: Terdapat pengaruh yang signifikan supervisi terhadap komitmen organisasi pada karyawan Badan Tenaga Nuklir Nasional (BATAN) PUSPIPTEK Serpong

Ha1.4: Terdapat pengaruh yang signifikan tunjangan terhadap komitmen organisasi pada karyawan Badan Tenaga Nuklir Nasional (BATAN) PUSPIPTEK Serpong

Ha1.5: Terdapat pengaruh yang signifikan penghargaan terhadap komitmen organisasi pada karyawan Badan Tenaga Nuklir Nasional (BATAN) PUSPIPTEK Serpong

Ha1.6: Terdapat pengaruh yang signifikan prosedur operasional terhadap komitmen organisasi pada karyawan Badan Tenaga Nuklir Nasional (BATAN) PUSPIPTEK Serpong

Ha1.7: Terdapat pengaruh yang signifikan rekan kerja terhadap komitmen organisasi pada karyawan Badan Tenaga Nuklir Nasional (BATAN) PUSPIPTEK Serpong

Ha1.8: Terdapat pengaruh yang signifikan sifat pekerjaan terhadap komitmen organisasi pada karyawan Badan Tenaga Nuklir Nasional (BATAN) PUSPIPTEK Serpong

Ha1.9: Terdapat pengaruh yang signifikan komunikasi terhadap komitmen organisasi pada karyawan Badan Tenaga Nuklir Nasional (BATAN) PUSPIPTEK Serpong

Ha2.1: Terdapat pengaruh yang signifikan central life interest terhadap komitmen organisasi pada karyawan Badan Tenaga Nuklir Nasional (BATAN) PUSPIPTEK Serpong

Ha2.2: Terdapat pengaruh yang signifikan active participation terhadap komitmen organisasi pada karyawan Badan Tenaga Nuklir Nasional (BATAN) PUSPIPTEK Serpong

Ha2.3: Terdapat pengaruh yang signifikan importance of performance with valued self terhadap komitmen organisasi pada karyawan Badan Tenaga Nuklir Nasional (BATAN) PUSPIPTEK Serpong

Ha2.4: Terdapat pengaruh yang signifikan consistency with self concept terhadap komitmen organisasi pada karyawan Badan Tenaga Nuklir Nasional (BATAN) PUSPIPTEK Serpong

\section{METODE PENELITIAN}

Penelitian ini menggunakan pendekatan kuantitatif dengan analisis multiple regression. Penulis menentukan sampel berdasarkan individu yang sesuai dengan kriteria yang telah ditentukan oleh penulis. Kriteria sampel dalam penelitian ini adalah karyawan yang telah bekrja minimal 1 tahun, karyawan tetap maupun tidak tetap, dan berusia (20-50) tahun. Sampel dalam penelitian ini berjumlah 200 orang yang ditentukan dengan teknik probability sampling. 
Skala yang digunakan untuk mengukur komitmen organisasi adalah skala yang disusun sendiri oleh peneliti, untuk mengukur komitmen organisasi menggunakan 3 dimensi dari Allen \& Meyer (1990). Mengukur Kepuasan kerja menggunakan 9 dimensi dari Spector (1997). Mengukur keterlibatan kerja menggunakan 4 dimensi dari Saleh \& Hosek (1976). setelah dilakukan uji validitas diperoleh hasil seluruh item valid.

\section{HASIL PENELITIAN}

Pada hasil analisis multiple regression diperoleh $R^{2}$ sebesar 0.357 atau $35,7 \%$. Artinya proporsi varians dari komitmen organisasi yang dijelaskan oleh semua independent variable adalah sebesar 35,7\%, sedangkan $64,3 \%$ sisanya dipengaruhi oleh variabel lain diluar penelitian ini.

Tabel 1

Anova $^{\mathrm{b}}$

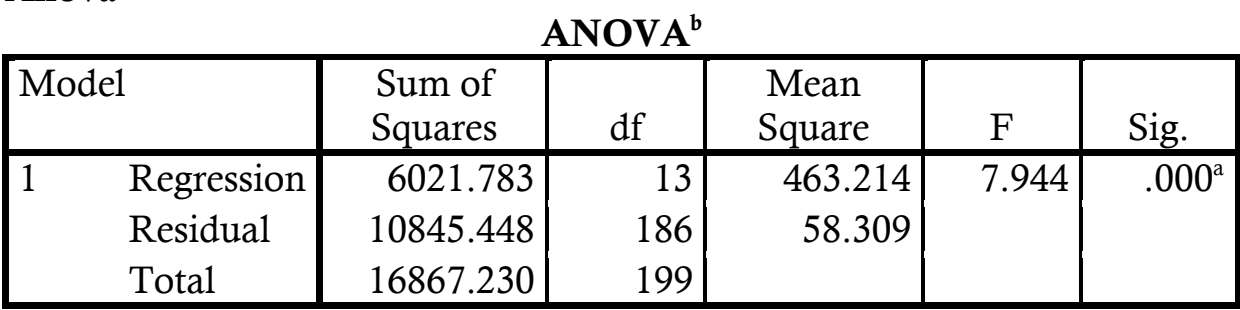

a. Predictors: (Constant), CSC, GAJI, KEBIJAKAN, AP, PROMOSI, TUNJANGAN, SUPERVISI, CLI, PENGHARGAAN, KOMUNIKASI, REKANKERJA, PEKERJAAN, IPV

b. Dependent Variable: KOMITMENORGANISASI

Tabel 1 menunjukkan bahwa model memiliki fit yang baik (sig > 0.05), yang mengindikasikan bahwa model regresi sesuai dengan data. Dengan kata lain dapat disimpulkan bahwa hipotesisi nihil yang menyatakan tidak ada pengaruh yang signifikan dari seluruh variabel independen ditolak. Artinya ada pengaruh yang signifikan kepuasan kerja dan keterlibatan kerja terhadap komitmen organisasi karyawan Badan Tenaga Nuklir Nasional (BATAN) PUSPIPTEK Serpong. 
Tabel 2

Koefisien Regresi

Coefficients $^{\mathrm{a}}$

\begin{tabular}{|l|r|r|r|r|r|}
\hline \multirow{2}{*}{ Model } & \multicolumn{2}{|c|}{$\begin{array}{c}\text { Unstandardized } \\
\text { Coefficients }\end{array}$} & $\begin{array}{c}\text { Standardized } \\
\text { Coefficients }\end{array}$ & & \\
\cline { 2 - 5 } & \multicolumn{1}{c|}{ B } & \multicolumn{1}{c|}{$\begin{array}{c}\text { Std. } \\
\text { Error }\end{array}$} & Beta & \multicolumn{1}{c|}{$\mathrm{t}$} & \multicolumn{1}{c|}{ Sig. } \\
\hline \multirow{2}{*}{1 (Constant) } & 6.596 & 8.572 & & .769 & .443 \\
GAJI & .080 & .088 & .061 & .917 & .360 \\
PROMOSI & .057 & .077 & .051 & .745 & .457 \\
SUPERVISI & -.097 & .084 & -.084 & -1.147 & .253 \\
TUNJANGAN & -.104 & .059 & -.113 & -1.779 & .077 \\
PENGHARGAAN & .048 & .061 & .055 & .787 & .432 \\
KEBIJAKAN & .017 & .062 & .018 & .273 & .785 \\
REKANKERJA & -.148 & .097 & -.128 & -1.531 & .127 \\
PEKERJAAN & .117 & .088 & .113 & 1.331 & .185 \\
KOMUNIKASI & .196 & .099 & .153 & 1.992 & .048 \\
CLI & -.087 & .071 & -.085 & -1.218 & .225 \\
AP & .094 & .084 & .090 & 1.117 & .265 \\
IPV & .318 & .103 & .270 & 3.072 & .002 \\
CSC & .376 & .070 & .370 & 5.409 & .000 \\
\hline
\end{tabular}

a. Dependent Variable: KOMITMENORGANISASI

a. Dependent Variabel: Komitmen organisasi

Berdasarkan koefisien regresi pada tabel di atas, dapat diketahui persamaan regresi sebagai berikut: ( ${ }^{*}$ signifikan)

Komitmen Organisasi $=6.596+.080$ gaji +.057 promosi -.097 supervisi -.104 tunjangan +.048 penghargaan +.017 prosedur operasional -.148 rekan kerja +.117 sifat pekerjaan $+.196^{*}$ komunikasi -.087 central life interest +.094 active participation $+.318^{*}$ important of performance with valued self $+.376^{*}$ consistency with self concept

Dapat dilihat bahwa hanya koefisien regresi hanya komunikasi, important of performance with valued self dan consistency with self concept yang signifikan. Hal ini berarti dari 13 hipotesis minor hanya 3 yang signifikan. Penjelasan dari nilai koefisien regresi yang diperoleh masing-masing IV adalah sebagai berikut:

1. Variabel Gaji

Diperoleh nilai koefisien regresi sebesar .080 dengan signifikansi .360 (sig > 0.05). Hal ini menunjukkan bahwa variabel gaji pada 
kepuasan kerja secara positif tidak berpengaruh secara signifikan terhadap komitmen organisasi.

2. Variabel Promosi

Diperoleh nilai koefisien regresi sebesar .057 dengan signifikansi .457 (sig > 0.05). Hal ini menunjukkan bahwa variabel promosi pada kepuasan kerja secara positif tidak berpengaruh secara signifikan terhadap komitmen organisasi.

3. Variabel Supervisi

Diperoleh nilai koefisien regresi sebesar -.097 dengan signifikansi .253 (sig > 0.05). Hal ini menunjukkan bahwa variabel supervisi pada kepuasan kerja secara positif tidak berpengaruh secara signifikan terhadap komitmen organisasi.

4. Variabel Tunjangan

Diperoleh nilai koefisien regresi sebesar -.104 dengan signifikansi .077 (sig > 0.05). Hal ini menunjukkan bahwa variabel tunjangan pada kepuasan kerja secara positif tidak berpengaruh secara signifikan terhadap komitmen organisasi.

5. Variabel Penghargaan

Diperoleh nilai koefisien regresi sebesar .048 dengan signifikansi .432 (sig > 0.05). Hal ini menunjukkan bahwa variabel penghargaan pada kepuasan kerja secara positif tidak berpengaruh secara signifikan terhadap komitmen organisasi.

6. Variabel Prosedur operasional

Diperoleh nilai koefisien regresi sebesar .017 dengan signifikansi .785 (sig > 0.05). Hal ini menunjukkan bahwa variabel prosedur operasional pada kepuasan kerja secara positif tidak berpengaruh secara signifikan terhadap komitmen organisasi.

7. Variabel Rekan Kerja

Diperoleh nilai koefisien regresi sebesar -.148 dengan signifikansi .127 (sig > 0.05). Hal ini menunjukkan bahwa variabel rekan kerja pada kepuasan kerja secara positif tidak berpengaruh secara signifikan terhadap komitmen organisasi.

8. Variabel Sifat pekerjaan

Diperoleh nilai koefisien regresi sebesar .117 dengan signifikansi .185 (sig > 0.05). Hal ini menunjukkan bahwa variabel sifat pekerjaan pada kepuasan kerja secara positif tidak berpengaruh secara signifikan terhadap komitmen organisasi.

9. Variabel Komunikasi

Diperoleh nilai koefisien regresi sebesar .196 dengan signifikansi .048 (sig < 0.05). Hal ini menunjukkan bahwa variabel komunikasi pada kepuasan kerja secara positif berpengaruh secara signifikan terhadap komitmen organisasi. Artinya 
semakin tinggi variabel komunikasi maka semakin tinggi pula komitmen organiasi.

10. Variabel Central Life Interest

Diperoleh nilai koefisien regresi sebesar -.087 dengan signifikansi .225 (sig > 0.05). Hal ini menunjukkan bahwa variabel Central Life Interest pada keterlibatan kerja secara positif tidak berpengaruh secara signifikan terhadap komitmen organisasi.

11. Variabel Active Participation

Diperoleh nilai koefisien regresi sebesar .094 dengan signifikansi .265 (sig > 0.05). Hal ini menunjukkan bahwa variable active participation pada keterlibatan kerja secara positif tidak berpengaruh secara signifikan terhadap komitmen organisasi.

12. Variabel Important of Performance with Valued Self

Diperoleh nilai koefisien regresi sebesar .318 dengan signifikansi .002 (sig < 0.05). Hal ini menunjukkan bahwa variable important of performance with valued self pada keterlibatan kerja secara positif berpengaruh secara signifikan terhadap komitmen organisasi. Artinya semakin tinggi variabel important of performance with valued self maka semakin tinggi pula komitmen organisasi.

13. Variabel Consistency with Self Concept

Diperoleh nilai koefisien regresi sebesar .376 dengan signifikansi .000 (sig < 0.05). Hal ini menunjukkan variabel consistency with self concept pada keterlibatan kerja secara positif berpengaruh secara signifikan terhadap komitmen organisasi. Artinya semakin tinggi variabel consistency with self concept maka semakin tinggi pula komitmen organisasi. 
Tabel 3

Model Summary

\begin{tabular}{|c|c|c|c|c|c|c|c|c|c|}
\hline & & & & & & & & & \\
\hline \multirow{2}{*}{ Model } & \multirow[b]{2}{*}{$\mathrm{R}$} & \multirow[b]{2}{*}{$\begin{array}{c}\mathrm{R} \\
\text { Square }\end{array}$} & \multirow[b]{2}{*}{$\begin{array}{c}\text { Adjusted } \\
\mathrm{R} \\
\text { Square }\end{array}$} & \multirow{2}{*}{$\begin{array}{l}\text { Std. } \\
\text { Error of } \\
\text { the } \\
\text { Estimate }\end{array}$} & \multicolumn{5}{|c|}{ Change Statistics } \\
\hline & & & & & $\begin{array}{c}\mathrm{R} \\
\text { Square } \\
\text { Change }\end{array}$ & $\begin{array}{c}\text { F } \\
\text { Change }\end{array}$ & df1 & $\mathrm{df} 2$ & $\begin{array}{c}\text { Sig. F } \\
\text { Change }\end{array}$ \\
\hline 1 & $.062^{2}$ & .004 & -.001 & 9.21211 & .004 & .758 & 1 & 198 & .385 \\
\hline 2 & $.175^{\mathrm{b}}$ & .031 & .021 & 9.11053 & .027 & 5.440 & 1 & 197 & .021 \\
\hline 3 & $.185^{\circ}$ & .034 & .019 & 9.11650 & .004 & .742 & 1 & 196 & .390 \\
\hline 4 & $.205^{\mathrm{c}}$ & .042 & .022 & 9.10383 & .008 & 1.546 & 1 & 195 & .215 \\
\hline 5 & $.205^{\mathrm{c}}-\mathrm{c}$ & .042 & .017 & 9.12701 & .000 & .011 & 1 & 194 & .917 \\
\hline 6 & .208 & .043 & .013 & 9.14496 & .001 & .239 & 1 & 193 & .625 \\
\hline 7 & $.208^{9}$ & .04 & .008 & 9.16745 & .000 & .054 & 1 & 192 & .817 \\
\hline 8 & $.252^{\mathrm{h}}$ & .063 & .024 & 9.09439 & .020 & 4.097 & 1 & 191 & .044 \\
\hline 9 & .283 & .080 & .036 & 9.03811 & .016 & 3.386 & 1 & 190 & .067 \\
\hline
\end{tabular}

Dari tabel 3 dapat diketahui berdasarkan koefisien beta, urutan independent variable yang memiliki pengaruh dari yang paling lemah hingga yang paling kuat terhadap munculnya komitmen organisasi pada para karyawan adalah komunikasi dengan nilai 0.153 lalu diikuti dengan importance of performance with valued self dengan nilai 0.270 lalu diikuti dengan consistency with self concept dengan nilai 0.370 .

\section{KESIMPULAN DAN SARAN}

\section{Diskusi}

Hasil yang diperoleh dalam penelitian ini menunjukkan bahwa kepuasan kerja dan keterlibatan kerja mempengaruhi tingkat komitmen organisasi karyawan secara signifikan. Dari Uji F, diperoleh F Hitung sebesar 7.944 dan signifikansi $\mathrm{p}=0.000$ atau jauh lebih kecil dari alpha $=$ $5 \%$ ini berarti hipotesis mayor yaitu ada hubungan positif yang signifikan antara kepuasan kerja dan keterlibatan kerja terhadap komitmen organisasi karyawan Badan Tenaga Nuklir Nasional (BATAN) PUSPIPTEK Serpong., diterima.

Berdasarkan data yang diperoleh melalui tabel di atas terlihat koefisien determinasi R Square $\left(\mathrm{R}^{2}\right)$ menunjukkan nilai 0.357 atau $35,7 \%$. Hal ini berarti bahwa kedua variabel yakni kepuasan kerja dan keterlibatan kerja memiliki pengaruh terhadap komitmen organisasi sebesar 35,7\%. Dengan demikian, variabel komitmen organisasi sebesar $64,3, \%$ sisanya dapat dijelaskan oleh variabel selain kepuasan kerja dan keterlibatan kerja. 
Hal ini mendukung penelitian sebelumnya yang dilakukan oleh Agho, Price \& Mueller, 1992 (dalam Buitendach \& De Witte, 2005) yang menjelaskan bahwa karyawan yang merasa puas dengan pekerjaannya akan menunjukkan komiten organisasi yang lebih baik. Hal ini sesuai dengan pengukuran Kreitner \& Kinicki, 2009 yang menjelaskan hasil dari 183 studi dan melibatkan 26.000 orang yang menyimpulkan ada hubungan yang signifikan dan positif antara komitmen organisasi dan kepuasan kerja.

Variabel pertama yang mempengaruhi komitmen organisasi dalam penelitian ini adalah kepuasan terhadap gaji. Hasil penelitian menunjukkan bahwa gaji memiliki konstribusi sebesar $0,4 \%$ diperoleh koefisien regresi sebesar 0.061 dengan signifikan $0.360(p>0,05)$. Artinya variabel gaji memiliki pengaruh positif terhadap komitmen organisasi akan tetapi tidak signifikan. Jadi semakin tinggi gaji maka semakin tinggi komitmen organisasi para karyawan.

$\mathrm{Hal}$ ini sesuai dengan penelitian yang dilakukan oleh Theriault (dalam Shaleh \& Yunita, 2006) yang menyatakan bahwa kepuasan kerja merupakan fungsi dari jumlah absolut dari gaji yang diterima, derajat sejauh mana gaji memenuhi harapan-harapan tenaga kerja, dan bagaimana gaji diberikan. Herzberg (dalam Munandar, 2003) memasukkan faktor gaji kedalam faktor kelompok hygiene. Jika dianggap gajinya terlalu rendah, tenaga kerja akan merasa tidak puas. Namun jika gaji dirasakan tinggi atau sesuai dengan harapan, maka menurut Herzberg, tenaga kerja akan merasa puas ketika individu sudah memiliki kepuasan kerja yang tinggi maka individu tersebut akan merasa aman dan nyaman dalam bekerja di instansi tersebut, sehingga bisa dikatakan individu yang mempunyai kepuasan kerja yang tinggi dalam hal gaji maka semakin tinggi pula komitmen organisasinya.

Variabel kedua yang mempengaruhi komitmen organisasi karyawan pada penelitian ini adalah promosi. Hasil penelitian menunjukkan bahwa promosi memiliki konstribusi sebesar 2,7 \% diperoleh koefisien regresi sebesar 0.051 dengan signifikan $0.457(\mathrm{p}>0,05)$. Artinya variabel promosi memiliki pengaruh positif terhadap komitmen organisasi akan tetapi tidak signifikan. Jadi semakin tinggi kepuasan terhadap promosi maka semakin tinggi komitmen organisasi para karyawan. Sebagaimana pendapat Robbins, 1993 (dalam Lumley dkk, 2011) promosi memberikan peluang untuk perkembangan individu, lebih bertanggung jawab dan meningkatkan status sosial. Kepuasan kerja diperoleh dari pengalaman kerja individu yang merasa mendapatkan peluang promosi yang adil, sehingga tidak berpikir untuk mencari profesi dan perusahaaan lain.

Variabel ketiga yang mempengaruhi komitmen organisasi dalam penelitian ini adalah kepuasan terhadap supervisi. Hasil penelitian menunjukkan bahwa supervisi memiliki konstribusi sebesar $0,4 \%$ diperoleh koefisien regresi sebesar -0.084 dengan signifikansi 0.253 ( $p>0,05)$. Artinya 
variabel supervisi memiliki pengaruh negatif terhadap komitmen organisasi dan tidak signifikan.

Menurut Locke (dalam Shaleh \& Yunita, 2006) tingkat kepuasan kerja yang paling besar dengan seorang atasan ialah jika kedua jenis hubungan adalah positif. Lebih lanjut Locke (dalam Munandar, 2006) mengemukakan dua jenis hubungan atasan-bawahan yaitu hubungan fungsional dan keseluruhan (entity). Hubungan fungsional mencerminkan sejauh mana penyelia membantu tenaga kerja, untuk memuaskan nilai-nilai pekerjaan yang penting bagi tenaga kerja. Sedangkan hubungan keseluruhan didasarkan pada ketertarikan antarpribadi yang mencerminkan sikap dasar dan nilai-nilai yang serupa. Dukungan dan perhatian dari atasan kepada karyawannya (supervisi) membuat karyawan merasa lebih bersemangat dalam bekerja dan merasa nyaman untuk meneruskan keanggotaanya dalam organisasi. Ketika hubungan positif antara karyawan dengan atasan terjalin maka hal tersebut bisa meningkatkan komitmen organisasi karyawan pada perusahaan.

Variabel keempat yang mempengaruhi komitmen organisasi dalam penelitian ini adalah kepuasan terhadap tunjangan. Hasil penelitian menunjukkan bahwa tunjangan memiliki konstribusi sebesar 0,8\% diperoleh koefisien regresi sebesar -0.113 dengan signifikan $0.077(p>0,05)$. Artinya variabel tunjangan memiliki pengaruh negatif terhadap komitmen organisasi dan tidak signifikan.

Menurut Suliman \& Iles, 2000 (dalam Lumley dkk, 2011) meningkatkan tunjangan intrinsik dan ekstrinsik yang menarik perhatian karyawan untuk meningkatkan prestasi mereka dan lebih meningkatkan komitmen organisasi.

Variabel kelima yang mempengaruhi komitmen organisasi dalam penelitian ini adalah kepuasan terhadap penghargaan. Hasil penelitian menunjukkan bahwa penghargaan memiliki konstribusi sebesar 0,0\% diperoleh koefisien regresi sebesar 0.055 dengan signifikan 0.432 ( $p>0,05)$. Artinya variabel penghargaan memiliki pengaruh positif terhadap komitmen organisasi akan tetapi tidak signifikan.

Menurut Spector, 1997 (dalam Lumley dkk, 2011), contoh dari penghargaan adalah apresiasi, pengakuan dan imbalan untuk kerja yang baik. Ketidakpuasan kerja karyawan bisa terjadi jika karyawan merasa upaya mereka tidak dihargai atau mereka tidak mendapat penghargaan yang wajar, hal ini sangat berkaitan dengan komitmen organisasi karyawan.

Variabel keenam yang mempengaruhi komitmen organisasi dalam penelitian ini adalah kepuasan terhadap prosedur operasional. Hasil penelitian menunjukkan bahwa prosedur operasional memiliki konstribusi sebesar $0,1 \%$ diperoleh koefisien regresi sebesar 0.018 dengan signifikan $0.785(\mathrm{p}>0,05)$. Artinya variabel prosedur operasional memiliki pengaruh positif terhadap komitmen organisasi akan tetapi tidak signifikan. 
Menurut Martins \& Coetzee, 2007 (dalam Lumley dkk, 2011) motivasi karyawan dan budaya organisasi di pengaruhi oleh bagaimana kebutuhan karyawan yang diintegrasikan dengan kebutuhan organisasi, adanya keseimbangan antara lingkungan pekerjaan dengan kehidupan pribadi karyawan akan meningkatkan komitmen organisasi.

Variabel ketujuh yang mempengaruhi komitmen organisasi dalam penelitian ini adalah kepuasan terhadap rekan kerja. Hasil penelitian menunjukkan bahwa rekan kerja memiliki konstribusi sebesar $0,0 \%$ diperoleh koefisien regresi sebesar -0.128 dengan signifikan $0.127(p>0,05)$. Artinya variabel rekan kerja memiliki pengaruh negatif terhadap komitmen organisasi dan tidak signifikan.

Hal ini tidak sejalan dengan teori Robbins, 1993 (dalam Lumley dkk, 2011). yang mengatakan memiliki teman yang ramah dan rekan kerja yang supportif dapat meningkatkan kepuasan kerja. Menurut Gazzawi, 2008 (dalam Lumley dkk, 2011) rekan kerja yang baik bisa menciptakan budaya organisasi yang positif dan juga bisa saling mengasah potensi karyawan tersebut, ketika hubungan positif ini terjalin maka kepuasan kerja dan juga komitmen organisasi akan meningkat.

Variabel kedelapan yang mempengaruhi komitmen organisasi dalam penelitian ini adalah kepuasan terhadap sifat pekerjaan. Hasil penelitian menunjukkan bahwa sifat pekerjaan memiliki konstribusi sebesar 2.0\% diperoleh koefisien regresi sebesar 0.113 dengan signifikan $0.185(\mathrm{p}>0,05)$. Artinya variabel sifat pekerjaan memiliki pengaruh positif terhadap komitmen organisasi akan tetapi tidak signifikan.

Shaleh \& Yunita, 2006 menyatakan bahwa bekerja dalam ruangan kerja yang sempit, panas, yang cahaya lampunya menyilaukan mata, kondisi kerja yang tidak mengenakkan (uncomfortable) akan menimbulkan keengganan untuk bekerja. Orang akan mencari-cari alasan untuk sering keluar ruangan kerjanya. Perusahaan perlu menyediaakan ruang kerja yang terang, sejuk, dengan peralatan kerja yang nyaman untuk digunakan, meja dan kursi yang dapat diatur tinggi rendah, miring tegak duduknya. Kondisi kerja yang memperhatikan prinsip-prinsip ergonomik. Dalam kondisi kerja seperti itu kebutuhan-kebutuhan fisik dipenuhi dan memuaskan tenaga kerja. Hal tersebut juga bisa menambah komitmen organisasi karyawan pada perusahaan.

Variabel kesembilan yang mempengaruhi komitmen organisasi dalam penelitian ini adalah kepuasan terhadap komunikasi. Hasil penelitian menunjukkan bahwa komunikasi memiliki konstribusi sebesar $1.6 \%$ diperoleh koefisien regresi sebesar 0.153 dengan signifikan 0.048 ( $p>0,05)$. Artinya variabel komunikasi memiliki pengaruh positif terhadap komitmen organisasi dan signifikan. Jadi semakin tinggi gaji maka semakin tinggi komitmen organisasi para karyawan.

Hal ini sejalan dengan Suehr, 1982 (dalam Wijono, 2011) mengatakan bahwa komunikasi adalah salah satu faktor penting dalam keseluruhan 
proses moral. Komunikasi dapat dilihat dari ketidakhadiran kerja yang cenderung menjadi sumber utama dari ketidakpuasan dengan syarat individu diletakan pada posisi penting dalam suatu jalinan komunikasi yang erat. Selanjutnya Leaviit, 1961 (dalam Wijono, 2011) menemukan bahwa kepuasan kerja yang tinggi di kalangan anggota kelompok adalah jika mereka diletakkan ke dalam jalinan komunikasi yang erat. Disamping itu, dia menemukan bahwa anggota kelompok yang tidak ikut ambil bagian merasa tidak puas dan tidak mau meneruskan pekerjaannya. Jadi jika jalinan komunikasi yang erat diciptakan terhadap semua anggota, maka akan terjadi kepuasan kerja yang tinggi bagi setiap anggota kelompok.

Selanjutnya variabel dari dimensi keterlibatan kerja yang mempengaruhi komitmen organisasi dalam penelitian ini adalah Central Life Interest. Hasil penelitian menunjukkan bahwa Central Life Interest memiliki konstribusi sebesar 3,4\% diperoleh koefisien regresi sebesar - 0.085 dengan signifikan $0.225(p>0,05)$. Artinya variabel Central Life Interest memiliki pengaruh negatif terhadap komitmen organisasi dan tidak signifikan. Hal ini tidak sejaalan dengan teori Lawler \& Hall, 1970 (dalam Ekmekci, 2011) yang mendefinisikan keterlibatan kerja sebagai tingkatan dimana seorang karyawan bekerja secara total untuk mencari jati diri dan juga untuk memenuhi kebutuhan. Ketika jati diri dan kebutuhan utama dapat terpenuhi dari perusahaan tersebut maka meningkat juga komitmen organisasinya.

Selanjutnya variabel dari dimensi keterlibatan kerja yang mempengaruhi komitmen organisasi dalam penelitian ini yaitu active participation. Hasil penelitian menunjukkan bahwa active participation memiliki konstribusi sebesar $6.7 \%$ diperoleh koefisien regresi sebesar 0.090 dengan signifikan $0.265(\mathrm{p}>0,05)$. Artinya variabel active participation memiliki pengaruh positif terhadap komitmen organisasi akan tetapi tidak signifikan. Menurut Wickert, 1951 (dalam Ekmekci, 2011) tersedianya peluang untuk menciptakan keputusan perusahaan sehingga karyawan merasakan memiliki kontibusi penting untuk kesuksesan perusahaan akan meningkatkan keterlibatan kerja dan komitmen organisasi.

Selanjutnya variabel dari dimensi keterlibatan kerja yang mempengaruhi komitmen organisasi dalam penelitian ini adalah yaitu Importance of Performance with Valued Self. Hasil penelitian menunjukkan bahwa Importance of Performance with Valued Self memiliki konstribusi sebesar $7.5 \%$ diperoleh koefisien regresi sebesar 0.270 dengan signifikan $0.002(\mathrm{p}<0,05)$. Artinya variabel Importance of Performance with Valued Self memiliki pengaruh positif terhadap komitmen organisasi dan signifikan. Jadi semakin tinggi Importance of Performance with Valued Self maka semakin tinggi komitmen organisasi para karyawan. Komitmen organisasi dan keterlibatan kerja adalah faktor penting yang menunjukkan pengaruh terhadap prestasi organisasi. Ekmekci, 2011 menyatakan bahwa karyawan yang mempunyai komitmen organisasi dan keterlibatan kerja yang tinggi 
menampilkan upaya atau kinerja yang terbaik ketika mereka merasa puas dan bahagia dengan organisasi mereka selama bekerja. Karyawan dengan keterlibatan kerja yang tinggi harusnya lebih komitmen dan termotivasi karena mereka tertarik dengan pekerjaan dan organisasi.

Selanjutnya variabel dari dimensi keterlibatan kerja yang mempengaruhi komitmen organisasi dalam penelitian ini adalah yaitu Consistency with Self Concept. Hasil penelitian menunjukkan bahwa Consistency with Self Concept memiliki konstribusi sebesar 10.1\% diperoleh koefisien regresi sebesar 0.370 dengan signifikan $0.000(p>0,05)$. Artinya variabel Consistency with Self Concept memiliki pengaruh positif terhadap komitmen organisasi dan signifikan. Jadi semakin tinggi Consistency with Self Concept maka semakin tinggi komitmen organisasi para karyawan. Chungthai, 2008 (dalam Ekmekci, 2011) berpendapat bahwa keterlibatan kerja hampir sama dengan komitmen organisasi dimana keduanya terkait dengan identifikasi karyawan dengan pengalaman kerjanya. Hal penelitian ini sesuai dengan pendapat Gurin dkk, 1960 (dalam Ekmekci, 2011) yang menjelaskan keterlibatan kerja tegantung pada ekspresi dan aktualisasi diri karyawan dalam pekerjaannya secara terus menerus.

\section{Saran}

Peneliti menyadari bahwa masih banyak kekurangan dan keterbatasan dalam penelitian ini sehingga dibutuhkan penelitian lebih lanjut untuk melengkapi kekurangan dan keterbatasan tersebut. Berdasarkan hasil penelitian yang diperoleh, peneliti membagi saran menjadi dua, yaitu saran teoritis dan saran praktis. Saran tersebut dapat dijadikan bahan pertimbangan bagi peneliti lain yang akan meneliti variabel dependen yang sama.

\section{Saran Teoritis}

a. Hasil penelitian ini yang menemukan bahwa pengaruh kepuasan kerja dan keterlibatan kerja terhadap komitmen organisasi hanya sebesar 35,7\% maka bagi peneliti lain yang tertarik meneliti variabel dependen yang sama agar melibatkan variabel independen lain yang mempengaruhi komitmen organisasi selain kepuasan kerja dan keterlibatan kerja, seperti faktor kepribadian (personality), budaya organisasi, iklim organisasi dan gaya kepemimpinan. Variabel kepribadian dianggap penting dalam penelitian komitmen organisasi karyawan. Hal ini dikarenakan bisa memberikan gambaran adanya pengaruh faktor internal dalam diri karyawan yang mempengaruhi komitmen organisasi karyawan. Seperti penelitian terdahulu, menunjukkan adanya pengaruh trait kepribadian Big Five yaitu trait Agreeableness terhadap komitmen organisasi. Dengan mempertimbangkan variabel-variabel tersebut, diharapkan 
penelitian selanjutnya akan lebih menyempurnakan hasil penelitian sebelumnya.

\section{Saran Praktis}

a. Untuk para atasan dapat menciptakan pengawasan yang fleksibel atau tidak terlalu kaku. Atasan dapat memberikan arahan, dorongan, dan sekaligus sebagai teman yang bersahabat serta tidak segan memberikan penghargaan bagi yang berprestasi dalam unjuk kerjanya dan sanksi bagi yang salah.

b. Berdasarkan hasil penelitian bahwa adanya pengaruh yang signifikan kepuasan kerja terhadap komitmen organisasi, terutama pada aspek komunikasi. Komunikasi yang dimaksud di sini adalah berbagai informasi yang sifatnya verbal maupun non verbal. Pada karyawan BATAN, terlihat bahwa mereka merasa pemenuhan kebutuhan akan informasi yang terjadi di dalam kantor menjadi penting. Variabel keterlibatan kerja pun memiliki pengaruh yang signifikan terhadap komitmen organisasi, terutama pada aspek importance of performance with valued self dimana usaha kerja yang ditampilkan menggambarkan seberapa jauh seseorang yang terlibat pada pekerjaannya akan menganggap penting pekerjaan tersebut bagi self-esteem atau rasa keberhargaan diri pada seseorang. Aspek lainnya yaitu consistency with self concept dimana individu yang terlibat dalam pekerjaannya akan memiliki konsentrasi terhadap unjuk kerja sehingga bisa mempengaruhi konsistensi seseorang dengan konsep dirinya. Oleh karena itu sebaiknya perusahaan memberikan kesempatan yang seluas-luasnya terhadap karyawannya untuk dapat bekerja dengan kreatif serta menambah ilmu sebanyak-banyaknya dan memberikan toleransi kepada karyawannya agar dapat bekerja secara bebas sesuai dengan kehendaknya tetapi dengan masih memberikan batas-batas yang sewajarnya. Dalam hal ini maka karyawan akan merasakan puas dalam bekerja dan dapat bekerja tanpa tekanan yang besar sehingga pafra karyawan dapat meningkatkan produktifitasnya dan rasa keberhargaan dirinya.

c. Hasil penelitian ini dapat dijadikan bahan masukan yang positif bagi perusahaan untuk lebih memperhatikan faktor-faktor yang dapat mempengaruhi komitmen organisasi. 


\section{DAFTAR PUSTAKA}

As'ad, M. (1980). Psikologi industri (2 nd ed.). Yogyakarta: Liberty Offset.

Blau, G. and K. Boal. (1989). "Using job involvement and organizational commitment interactively to predict turnover." Journal of Management, 15: 115-127.

Blau, G. J. \& K. B. Boal. (1987). "Conceptualizing how job involvement and organizational commitment affect turnover and absenteeism." Academy of Management Review, 12: 288-300.

Brown, S. P. \& T. W. Leigh. (1996). "A new look at psychological climate and its relationship to job involvement, effort, and performance." Journal of Applied Psychology, 81: 358-368.

Buitendach, J. H. and H. De Witte. (2005). "Job insecurity, extrinsic and intrinsic job satisfaction and affective organisational commitment of maintenance workers in a parastatal. "Southern African Journal Business and Management, 36: 27-34.

Cook, J. and T. Wall. (1980). "New work attitude measures of trust, organizational commitment and personal need non-fulfilment." Journal of Occupational Psychology, 53: 39-52.

Ekmecki,A.K. (2011). "A study on involvement and commitment of employees in Turkey." Journal of Public Adsministration and Policy Research, 3: 68-73.

Hallberg, U. E. and W. B. Schaufeli. (2006). "Same-same but different ? can work engagement be discriminated from job involvement and organizational commitment?." European Psychologist, 11: 119-129.

Jewell, L. N. \& M. Siegall. (1990). "Contemporary industrial/ organizational psychology." West Publishing Company.

Jewell, L. N. \& M. Siegall. (1998). "Psikologi industri/ organisasi modern." Jakarta: Arcan.

Kreitner, R. and Kinicki, A. (2009). "Organizational behavior ( $8^{\text {th }}$ ed)." New York: McGraw-Hill Companies.

Levy, P. E. (2006). "Industrial / organizational psychology : understanding the workplace (2 nd ed.)." U. S . A: Houghton Mifflin Company.

Lumley, E.J., M. Coetzee, M., R. Tladinyane, \& N. Ferreira. (2011). "Exploring the job satisfaction and organizational commitment of employees in the information technology environment." Southern African Business Review, 15: 100-118.

Mathieu, J. E. and D. M. Zajac. (1990). "A review and meta-analysis of the antecendents, correlates, and consequences of organizational commitment." Psychological Bulletin, 108: 171- 194.

Mathieu, J. E. and J. L.Farr. (1991). "Further evidence for the discriminant validity of measures of organizational commitment, job involvement, and job satisfaction." Journal of Applied Psychology, 76: 127-133. 
Meyer, J. P. and N. J. Allen. (1990). "The measurement and antecendents of affective, continuance and normative commitment to the organization." Journal of Occupational Psycholog, 63: 1-18.

Meyer, J. P. and N. J. Allen. (1991). "A three-component conceptualization of organizational commitment." Human Resource Management Review, 1: 61-89.

Meyer, J. P., David, J. S., Lynne, H., \& Laryssa, T. (2002). "Affective, continuance, and normative commitment to the oganization: a meta-analysis of antecendents, correlates, and consequences." Journal of Vocational Behavior, 61, 20-52.

Miner, John B. (1992). "Industrial-organizational psychology." NewYork:McGraw-Hill,Inc.

Muhadi. (2007). "Analisis pengaruh kepuasan kerja terhadap komitmen organisasional dalam mempengaruhi kinerja karyawan." Tesis. Semarang: Program Pasca Sarjana Manajemen Universitas Diponegoro.

Munandar, A. S. (2006). Psikologi industri dan organisasi. Jakarta: UI Press.

Schultz, D. P., \& Sydney, E. S. (2010). Psychology and work today (10 ${ }^{\text {th }}$ ed.). University of South Florida: Pearson Education, Inc.

Shaleh, A. R., \& Yunita, F. N. (2006). Psikologi \& industri (1 st ed.). Jakarta: UIN Press.

Sopiah. (2008).Perilaku organisasional Yogyakarta: ANDI.

Spector, P. E. (1994). "Job satisfaction survey." Departement of Psychology: University of South Florida.

Spector, P. E. (2000). Industrial and organizational psychology (2 nd ed.). University of South Florida: John Willey \& Sons, Inc.

Wijono, S. (2011). Psikologi industri dan organisasi: dalam suatu bidang gerak psikologi sumber daya manusia. Jakarta: Kencana.

Yekty, R. P. (2006). "Analisis pengaruh iklim psikologis terhadap keterlibatan kerja dan kepuasan kerja dalam meningkatkan kinerja karyawan." Tesis. Semarang: Program Pasca Sarjana Manajemen Universitas Diponegoro.

File:///D:/My\%20Documents/Unduhan/pentingnya-komitmen-dalam-

suatu-perusahaan-atau-organisasi-577535.html diunduh pada tanggal 10-03-2013. 